Revue Française de Civilisation Britannique

XXII-1 | 2017

The Book of Common Prayer : Studies in Religious

Transfer

\title{
The Political Enforcement of Liturgical Continuity in the Church of England 1558-1662
}

L'imposition par le pouvoir politique de la continuitéliturgique dans l'Eglise

d'Angleterre, 1558-1662

\section{Claire Cross}

\section{OpenEdition \\ Journals}

Electronic version

URL: http://journals.openedition.org/rfcb/1215

DOI: $10.4000 /$ rfcb. 1215

ISSN: 2429-4373

Publisher

CRECIB - Centre de recherche et d'études en civilisation britannique

Electronic reference

Claire Cross, « The Political Enforcement of Liturgical Continuity in the Church of England 1558-1662

», Revue Française de Civilisation Britannique [Online], XXII-1 | 2017, Online since 02 May 2017,

connection on 20 April 2019. URL : http://journals.openedition.org/rfcb/1215; DOI : 10.4000/

rfcb. 1215

This text was automatically generated on 20 April 2019.

\section{cc)}

Revue française de civilisation britannique est mis à disposition selon les termes de la licence Creative Commons Attribution - Pas d'Utilisation Commerciale - Pas de Modification 4.0 International. 


\title{
The Political Enforcement of Liturgical Continuity in the Church of England 1558-1662
}

\author{
L'imposition par le pouvoir politique de la continuité liturgique dans l'Eglise
}

d'Angleterre, 1558-1662

\section{Claire Cross}

1 The preservation of the liturgy in the mid sixteenth century, which revisions of the Book of Common Prayer altered little, was primarily caused by reasons of state, but this relative continuity with the medieval liturgical past, was bought at a very considerable price. Secular politics have impacted upon the Book of Common Prayer throughout its history, not least because the passage of the 1559 Act of Supremacy, which once more recognised the monarch as both the head of the English state and the supreme governor of the English church, automatically made objections to the Prayer Book a potential infringement of royal authority. Time and again during the century between the accession of Elizabeth and the restoration of Charles II moderate and radical Protestants alike raised concerns over whether the liturgy of the Prayer Book accurately reflected the doctrine of the national church: the failure to address these issues contributed in no small measure to the destruction of a comprehensive Protestant church in England in 1662.

The Book of Common Prayer was far from being set in aspic when Elizabeth succeeded to the throne in November 1558. Despite his renunciation of the papacy, Henry VIII had remained conservative in many other aspects of religion, and allowed only a few alterations in the church's worship. It was only when the reformers seized control on the accession of Edward VI in January 1547 that a wholesale revision of the liturgy took place, starting with the publication of a Communion Service in the vernacular in 1548. A convinced evangelical by this date, Cranmer had nevertheless moved very cautiously when compiling the First Book of Common Prayer of 1549, and kept as much of the traditional pattern as he could. When, however, his opponents had begun interpreting 
the 1549 Prayer Book in a Catholic sense, he had devised a second unequivocally Protestant Prayer Book in 1552. This second Prayer Book had been in use for a mere three quarters of a year when Edward VI died on 6 July 1553 and his half sister Mary I brought back the old Catholic liturgy and returned the country to the papal fold. ${ }^{1}$

Once they had reached the relative safety of the Continent, the first contingent of Protestant clergy and laity, fleeing the country on account of their religion, were more than ready to abandon the 1552 Book of Common Prayer and model their worship upon that of their hosts. Some later arrivals, however, insisted on its retention at least partly as a sign of their English identity. The attempt by Richard Cox and his party to impose the Prayer Book on the English congregation at Frankfort resulted in half the community migrating with John Knox to Geneva. Yet even the members of the church who stayed in Frankfort conceded in a letter to Calvin in April 1555 that the second Edwardian Prayer Book still contained some imperfections, which they had recently taken it upon themselves to amend:

when the magistrates lately gave us permission to adopt the rites of our native country we freely relinquished all those ceremonies which were regarded by our brethren as offensive and inconvenient. For we gave up private baptism, confirmation of children, saints days, kneeling at the holy communion, the linen surplice of the ministers, crosses, and other things of the like character. ${ }^{2}$

Most of the exiles returned in haste to England on Mary's death on 17 November 1558 to discover to their chagrin that they could exert very little direct influence on the religious settlement. The new Protestant government faced considerable opposition to making any change in religion, and with the Catholic bishops still ensconced in the House of Lords only succeeded by a hair's breadth just after Easter in persuading Parliament to pass the Acts of Supremacy and Uniformity, which respectively acknowledged the crown as the supreme governor of the English church and decreed that all ministers throughout the country be 'bounden to say and use' the Prayer Book, and no other formulary, from 24 June 1559. Apart from the inclusion of the words of administration at holy communion from the first Edwardian Prayer Book, the Elizabethan Prayer Book differed very little from the second Prayer Book of Edward VI. Probably because Calvin himself held more than a memorialist view of the Lord's supper, this particular change does not seem to have troubled Protestants bent on further reform. What seriously concerned them was the rubric which directed that 'such ornaments of the church and of the ministers thereof shall be retained and be in use as was in this church of England by authority of Parliament in the second year of the reign of King Edward the VI'. To those who had so recently observed the 'best' reformed churches on the Continent at first hand it now seemed intolerable to have to re-adopt the garb of the Catholic priesthood. The former exile and incoming bishop of Worcester, Edwin Sandys, indeed could not believe that the vestments clause would apply to convinced Protestants: 'our gloss upon this text', he wrote in late April 1559, 'is that we shall not be forced to use them.' At around the same time John Jewel, the future bishop of Salisbury and author of the classic defence of the English church, referred disparagingly to 'the scenic apparatus of divine worship'. Even though in practice the new Elizabethan bishops appear only to have required parochial clergy to wear the vestments in use at the death of Edward VI, that is to all intents and purposes the surplice, the rubric remained a major stumbling block for those striving to secure a fully reformed church in England. ${ }^{3}$

5 The vestments rubric contained the provision that it should continue in operation "until other order shall be therein taken by authority of the queen's majesty with the advice of 
her commissioners appointed and authorised under the great seal of England for causes ecclesiastical or of the metropolitan of this realm", and for a decade at least many leading churchmen anticipated vestments and ceremonies specified in the Prayer Book might be modified if not dispensed with altogether. At the national synod of the clergy in 1562 Bishop Sandys moved that the queen should be petitioned that "private baptism might be taken out of the Book of Common Prayer' and that 'the collect for crossing of the infant in the forehead may be blotted out, as it seems very superstitious, so it is not needful.' The appeal achieved nothing. With a similar lack of success, the more forward clergy at the 1563 synod attempted to excise from the Prayer Book the observance of saints' days, kneeling at communion, signing with the cross at baptism, and the clergy's obligation to wear the surplice during worship and a distinctive outdoor dress when they went abroad. The approval by this Convocation of the Thirty-Nine Articles, a condensed and somewhat modified version of the indisputably Protestant Forty-Two Articles of the last year of Edward VI, and their subsequent endorsement by Parliament in 1571, drew yet further attention to the discrepancy between the church's doctrine and the quasi-Catholic practices countenanced by the Book of Common Prayer. ${ }^{4}$

6 Stymied in Convocation, clergy with scruples over the Prayer Book turned to their lay sympathisers for support. In London and its hinterland numerous congregations sheltered ministers who refused to wear the surplice. Enticed to Hull from Boston in Lincolnshire by a group of forward councillors, Melchior Smith in the 1560s delegated the reading of Prayer Book services in Holy Trinity church to curates and clad in a Genevan gown only appeared in the pulpit to preach. The protection of the godly third earl of Huntingdon enabled the Marian exile and very vocal opponent of vestments, Anthony Gilby, to promote the cause for reform from the Hastings family seat at Ashby de la Zouch in Leicestershire virtually unscathed for over two decades until his death in $1585 .^{5}$

7 Having encountered this type of passive resistance on her progresses across southern England, at the beginning of 1565 Elizabeth insisted upon the enforcement of uniformity in the matter of clerical dress. The ensuing Vestiarian Controversy split the reformers. In Oxford, the former exiles Laurence Humphrey and Thomas Sampson, now respectively president of Magdalen College and dean of Christ Church, rejecting the argument that vestments might be regarded as a matter of indifference to be imposed at the will of the civil magistrate, felt called to make a stand. At the height of the dispute, after admitting to Bullinger 'we have (praised be God!) a doctrine pure and incorrupt,' they asked rhetorically, "why should we go halting in regard to divine worship, which is not the least

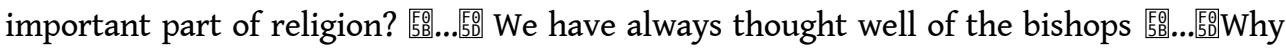
do they cast us into prison? Why do they persecute us on account of the habits?' For their part, some of the bishops had qualms about what their supreme governor was constraining them to do, as Grindal and Horn some months later told Bullinger and Gualter, explaining that they had been acting at the queen's behest and that they still wished the vestments rubric could be dropped together with the practice of signing with the cross at baptism and kneeling at communion. Saved by a legal nicety Humphrey rode out the storm at Magdalen, but Sampson lost the deanery of Christ Church, a crown appointment, and a number of the lesser clergy were deprived of their livings for refusing to conform. From the time of the Vestiarian Controversy the hotter sort of Protestants increasingly looked upon the bishops as their adversaries, while some now began questioning the legitimacy of the very institution of episcopacy. Then in lectures on the New Testament delivered at Cambridge university in 1570 Thomas Cartwright advanced 
the revolutionary proposition that rather than the regulation of the church being a matter of indifference and so open to modification by the secular power Presbyterianism alone was the divinely sanctioned form of church government. ${ }^{6}$

While by this date reformers had despaired of gaining change through Convocation, they had not entirely abandoned hope of Parliament. They introduced bills to impose a stricter code of ecclesiastical discipline and to purge the Prayer Book of the hated ceremonies in the Parliament of 1571, but made no progress whatsoever in the face of the queen's opposition. Though they must have known very well how she would react, a group of laymen still sponsored another bill for the reform of the Prayer Book in the Parliament of 1572. Some radicals, however, had lost all patience with the policy of waiting upon the magistrate and before that session of Parliament had even come to an end two young ministers, Thomas Wilcox and John Field, took the decision to move the debate out into the market place, and to appeal to the nation at large. ${ }^{7}$

9 In their tract, misleadingly entitled An Admonition to the Parliament, they launched a scathing attack on the Prayer Book in language deliberately designed to court the populace. 'We must needs say ... that this book is an unperfect book, culled and picked out of that popish dunghill, the Mass Book, full of abominations.' It contained a host of totally unacceptable observances: 'private communion, private baptism, baptism ministered by women, holy days ascribed to saints, prescript services for them, kneeling at communion, wafer cakes for their bread when they minister it, surplice and cope to do it in, churching of women coming in veils...' The laity, moreover, derived little benefit from this form of worship:

In all their order of service there is no edification, according to the rule of the apostle, but confusion. They toss the psalms in most places like tennis balls. The people some standing, some walking, some talking, some reading, some praying by themselves, attend not to the minister. 監...監 As for organs and curious singing, though they be proper to popish dens, I mean the cathedral churches, yet some others also must have them. The queen's chapel and these churches must be patterns and precedents to the people of all superstitions.

10 They then moved on to the habits, marvelling that the church should still have kept 'copes, caps, surplices, tippets, and such like baggage, the preaching signs of popish priesthood, the pope's creatures. ${ }^{\text {8 }}$

11 Most fundamentally of all the admonitioners believed that the Prayer Book, since it did not provide for sermons at the main services as a matter of course, seriously hindered the church's teaching ministry. When conscientious clergy took it upon themselves to preach, as they considered that it was their obligation to do every Sunday, the sheer length of the set service, in the morning mattins followed by the ante-communion, limited the time available for the sermon. Some conservatives even preferred the reading of printed homilies to sermons, and

in the fulness of their blasphemy have said that much preaching bringeth the word of God into contempt, and that four preachers were enough for all London, so far are they from thinking it necessary, and seeking that every congregation should have a faithful pastor. ${ }^{9}$

During the 1560s theological exercises known as prophesyings, intended to educate the parochial clergy and improve their capacity to preach, had sprung up in many parts of the country. When she heard about them, because of their voluntary nature Elizabeth saw them as threats to the hierarchical government of the church, and commanded the archbishop of Canterbury, Matthew Parker, to suppress them. After his death in 1575 the 
unwelcome task fell to his successor, Edmund Grindal. Moved to the quick after she had spoken slightingly of preaching in his presence, the new archbishop felt compelled to speak his mind, and taking his inspiration from the remonstration addressed to the emperor Theodosius by St Ambrose in the fourth century composed a public letter to the queen:

Alas, madam! Is the scripture more plain in any one thing than that the gospel of Christ should be plentifully preached? 區...豎 Public and continual preaching of God's word is the ordinary mean and instrument of the salvation of mankind. 孯...嚚 The reading of homilies hath his commodity, but is nothing comparable to the office of preaching 㯺which had been greatly advanced by臨 the learned exercise and conference amongst the ministers of the church

He had rather surrender his office than curb preaching. He concluded by reminding the supreme governor of her obligations to the church:

Remember, madam, that you are a mortal creature. And although ye are a mighty prince, yet remember he which dwelleth in heaven is mightier. Wherefore I do beseech you, madam, in visceribus Christi, when you deal in these religious causes, set the majesty of God before your eyes, laying all earthly majesty aside, determine with yourself to obey his voice, and with all humility say unto him, Non mea sed tua voluntas fiat..$^{10}$

13 Greatly offended, the queen ordered Grindal's sequestration, and he never regained his powers of office. His sufferings, however, did much to redeem the institution of episcopacy in the eyes of more radical Protestants and so long as he lived the voices calling for the Presbyterian form of the church government fell silent. Everything changed when he died and John Whitgift succeeded him as archbishop of Canterbury in the autumn of 1583. A disciplinarian, Whitgift at once set to work to impose a greater uniformity upon the church and as a means to that end required the clergy to give their formal consent to three propositions. Most had no problem in acknowledging the royal supremacy and the Thirty-Nine Articles, but the more scrupulous among them could not in conscience accept 'that the Book of Common Prayer and of ordering bishops, priests and deacons containeth nothing in it contrary to the word of God.' In the ensuing outcry Burghley accused the archbishop of acting like a Roman inquisitor, and Whitgift had eventually to content himself with a limited subscription. The damage, however, was done, the bishops appeared once again to have resumed the role of persecutors, and the hotter sort of Protestants considered they had every justification in renewing their attacks on the institution of episcopacy. ${ }^{11}$

Throwing caution to the winds, in parts of the south of England, the Midlands and East Anglia some ministers now began implementing a voluntary form of Presbyterianism within the national church, meeting in local, regional and occasionally national synods. In 1586 Sir Anthony Cope even went so far as to introduce a bill into the House of Commons to replace the Prayer Book with the Genevan liturgy and the ancient system of canon law with a much stricter Presbyterian discipline. United in the defence of episcopacy the bishops retaliated by prosecuting Cartwright and his associates first in the Court of High Commission and then in the Star Chamber. Although they failed to convict them of high treason, they nevertheless succeeded in crushing the movement and gagging its protagonists for the remainder of the reign. ${ }^{12}$

The defeat of Presbyterianism, however, did nothing to silence criticism of the Book of Common Prayer. Drawing up his will a year before he died in 1588 no less a churchman 
than Edwin Sandys, archbishop of York and second only to the archbishop of Canterbury in the episcopal hierarchy, recorded for posterity his desire for its further reform: concerning rites and ceremonies by political constitutions authorized amongst us, as I am and have been persuaded that such as are now set down by public authority in this church of England are no way either ungodly or unlawful, but may with good

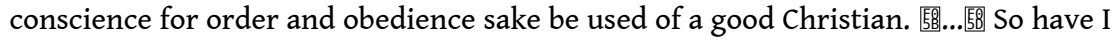
ever been and presently am persuaded that some of them be not so expedient in this church now, but that in the church reformed, and in all this time of the gospel (wherein the seed of the scripture hath so long been sown), that they may better be disused by little and little, than more and more urged. ${ }^{13}$

Aspirations were one thing, their realisation another and by this date it must have become evident to moderates and radicals alike that the present queen would allow no alterations to the Prayer Book during her life time. Everything changed in 1603 on the accession of James I, a Scot educated from infancy in an indubitably fully reformed church, and within a month of Elizabeth's death the new monarch received a petition from allegedly a thousand of his subjects "for the reformation of certain ceremonies and abuses of the church". Deliberately moderate in tone the petition repeated the calls for reform made so frequently in the previous half century - that "the cross in baptism ... be taken away", that "church songs and music be moderated to better edification", "that examination may go before the communion", and "that men be not excommunicated without the consent of the pastor". It also asked that newly ordained ministers should in the future only be required to acknowledge the royal supremacy and declare their assent to the articles of religion. ${ }^{14}$

Unlike Elizabeth, James positively enjoyed theological disputation, and responded to the petition by presiding over a conference at Hampton Court in January 1604. The king sympathised with the reformers' call for a greater supply of learned preachers and for a new translation of the Bible, but, highly sensitive to any infringement of his position as supreme governor, exploded in anger when he mistakenly thought John Reynolds was suggesting that a modified form of Presbyterianism should be introduced into the English church. The conference ended with the king impressing upon the petitioners the virtue of obedience and urging them to appeal to him personally if they felt the bishops were treating them too harshly. Apart from the insertion of clauses disallowing baptism by midwives and justifying the rite of confirmation, the edition of the Prayer Book, issued a mere three weeks later, was in all other respects identical with the Book of Common Prayer of $1559 .{ }^{15}$

Particularly during the archiepiscopate of Richard Bancroft, who occupied the see of Canterbury between 1604 and 1610, clergy continued to be excluded from their livings for refusing to observe the rites and ceremonies prescribed in the Book of Common Prayer, though even the king conceded that these "puritans and novelists" did "not so far differ from us in points of religion as in their confused form of policy and parity". For their part, so long as James remained the supreme governor and a Calvinist consensus prevailed in religion the great majority of ministers felt able to exercise their vocation within the church, taking comfort in the fact that in all essentials its doctrine accorded with that of the best reformed churches on the Continent. ${ }^{16}$

This way of thinking, however, was totally antipathetic to a theological movement which had been growing in strength in the two universities since the last decades of the previous century. Derided as Arminians, these opponents of Calvinism, who rejected predestination in favour of freewill, placed the sacraments above sermons and no longer 
held the pope to be the Antichrist, seemed to their antagonists to be about to be reintroducing Catholicism by the back door. James I had been cautious in promoting such churchmen, but the moment Charles I succeeded his father in 1625 the gates of patronage sprang wide open. In a mere three years the party's leader, William Laud, progressed from the insignificant Welsh bishopric of St David's via Bath and Wells to London in the knowledge that the see of Canterbury would become his so soon as it fell vacant. His older colleague, Richard Neile, achieved an equally rapid advance from Durham to Winchester and then York. Alarmed by the Arminians' capture of so many of the chief posts in the church, Parliament in 1629 called upon Charles to preserve "the orthodox doctrine of our church 臨....5 according as it hath been hitherto generally received, without any alteration or innovation" and only "to confer bishoprics, and other ecclesiastical preferments, with the advice of his privy council, upon learned, pious and orthodox men". ${ }^{17}$

Ignoring their protests, Charles chose to rule without a Parliament, and gave the Arminians free rein. Laud and his followers then proceeded to implement their programme largely through a literal enforcement of the observances and practices set out in the Book of Common Prayer. Their campaign to bring worship in parish churches into harmony with the far more elaborate liturgy celebrated in cathedrals, collegiate churches and royal chapels met with widespread resistance from influential sectors of the laity, who in particular opposed the requirement that the holy table, which for generations had been brought down into the body of the church for the communion service, be now situated permanently altar wise at the east end of the chancel and railed. To curb preaching the Laudians went on to order clergy to replace afternoon sermons, for which there was no provision in the Prayer Book, with regular catechising, and attempted to put an end the practice of sermon gadding by forcing the laity to attend all services in their parish church. ${ }^{18}$

21 The implementation of this policy aroused resentment throughout the country, especially in towns like Salisbury, where the civic elite suffered a particularly humiliating defeat. The vestry of St Edmund's, one of Salisbury's three parishes, dominated by Henry Sherfield, the city's recorder and representative in Parliament between 1624 and 1629, and a prominent goldsmith, John Ivie, had recently acquired the advowson and in 1623 appointed a known reformer, Peter Thatcher. The new minister had then gone on to endorse from the pulpit the corporation's wide ranging plans for the creation of a godly commonwealth, only to be stopped in his tracks when Sherfield, in 1630, ill-advisedly took it upon himself to destroy a stained-glass window in St Edmund's which depicted God in the act of creating the world. In the ensuing Star Chamber trial, in which Sherfield was found guilty of iconoclasm, Laud went out of his way to incriminate Thatcher, who, he alleged, had "not read all the divine service a whole year together". After Sherfield's disgrace a group of disillusioned parishioners, which included the minister's teenage son, left Salisbury in despair for New England, and Thatcher himself for a time contemplated retiring to a safe haven in Herefordshire. In the event, he remained with his flock, and his harassment by the ecclesiastical authorities seems only to have increased his standing in popular estimation. Throughout the decade, the laity continued to relish his preaching, and no fewer than thirty-seven members of the adjoining parish of St Thomas appeared in the local church court in 1637 for neglecting services in their own church to frequent Thatcher's sermons. ${ }^{19}$ 
22 At the other end of England the chief inhabitants of the prosperous parish of St Martin's, Micklegate, in York had similarly acquired the patronage of their church. In 1633 they conferred the cure on John Birchill, who then proceeded to combine his parochial duties with acting as the household chaplain to Thomas Hoyle, a leading merchant and member of the corporation. Hoyle had recently purchased a small estate in Colton, a hamlet some half a dozen miles from the city and on a summer's day in 1635 Hoyle, his wife, daughter, Birchill and friends made an excursion into the country to visit his manor house. Before venturing out into the fields, Hoyle requested Birchill to offer up a prayer, which he did, asking God to

bless our king, queen and whole state, giving also thanks to God for his mercies spiritual and temporal and for the temporal mercies here and elsewhere given to Alderman Hoyle and his, together with a desire that we might rightly use them. And that he would bless them to us and our posterity. ${ }^{20}$

News of the expedition quickly reached the ecclesiastical authorities who accused Birchill of holding an illegal conventicle and of praying in an ex tempore manner in contempt of the Book of Common Prayer. Having pursued him for the rest of the decade the court inflicted a final indignity upon the ailing minister in March 1640 by requiring him to

read divine service in his parish church of St Martin's as is prescribed in the Book of Common Prayers established in the Church of England, and in his sermon upon Sunday next and in some passages of his other sermons hereafter to justify, maintain and defend the same to be both pious, lawful and well pleasing unto God and to enforce it to his parishioners. ${ }^{21}$

24 For eleven years from 1629 lay supporters of clergy like Thatcher and Birchill had no national forum in which to seek redress. The wheel then turned full circle. To raise supplies to put down the rebellion north of the border, caused in no small part by Laud's attempt to impose the Book of Common Prayer upon the Scots, the king had no alternative but to call a Parliament. The moment they gathered in Westminster in November 1640 members of the House of Commons began voicing their grievances over prelacy and the Prayer Book, with the more extreme seeking a total overhaul of the church's government, and some Londoners as early as December calling upon Parliament to eradicate episcopacy "root and branch". In January, Parliament received a petition from eighty Suffolk ministers for the reformation of the Prayer Book and, to that end, set up a committee two months later under the leadership of John Williams, Laud's archenemy, recently elevated to the archbishopric of York. On the passing of the Grand Remonstrance, which included a demand for the abolition of "needless and superstitious ceremonies 原...医 among much else to the removal of 'any illegal innovations' introduced into the Prayer Book. These concessions, however, were too little and too late. ${ }^{22}$

In parts of the country, radicals were already starting to take the law into their own hands, venting their anger at first on some of the greater churches. In Norwich, the mob burst into the cathedral, dragged out service books, vestments and organ pipes and set them on fire in the market place. Similar iconoclasm happened at Canterbury cathedral with prayer books pulled apart and strewed around the aisles. Then lesser churches came under attack. Holding that the prayer book "was a popish book and against the word of God", William Harvie of Earls Colne in Essex took "the Common Prayer Book out of his parish church on a Sunday morning" and threw "the same into a pond of water, and the next day, finding it swimming, took the same and tearing it to pieces threw part of it into the fire and burnt it". ${ }^{23}$ 

governing class rallied to the Prayer Book and began petitioning Parliament in its support. Kentish petitioners claimed that "the solemn liturgy of the Church of England" was "embraced by the most and best of all the laity", Lancashire petitioners that the Prayer Book enjoyed the "general approbation of the most pious and learned of this nation", while those from Cornwall extolled "the divine and excellent form of Common Prayer". Yet despite their veneration for the Prayer Book virtually all the petitioners drew the line at the changes introduced by the Laudians, with those from Bedfordshire inserting a specific clause condemning "the exorbitances of ecclesiastical jurisdiction and the innovations lately obtruded upon our church". What most of these conservatives seem to have wanted was a return to what they now regarded as the golden age of the English church in the reigns of Elizabeth and James. ${ }^{24}$

Throughout 1641 and the first half of 1642 , moderates on both sides continued in their efforts to devise a modified form of episcopacy and a reformed Book of Common Prayer, but time was against them. The outbreak of the Civil War in August 1642 had the effect of polarising attitudes towards the Prayer Book yet further, with Royalists making a point of observing it to the letter, Parliamentarians increasingly ready to dispense with it altogether. In the event, military exigencies decided the issue. Having come to the realisation that the king's forces could not be defeated without aid from abroad, Parliament had little choice in September 1643 but to enter into the Solemn League and Covenant with the Scots, and to accede to their demand that the government and liturgy of the English church should be brought into accord with that of the church in Scotland. After long periods of deliberation, the Assembly of Divines duly produced a guide for extempore worship, the Westminster Directory, and in the first week of January 1645 Parliament passed an ordinance requiring all parish churches to adopt this new form of service and banned the Book of Common Prayer. ${ }^{25}$

For the next fifteen years, the Prayer Book went underground, its clandestine use in England seen as a sign of political subversion if not potential treason, and the only place it could be openly employed in worship was at the royal court in exile on the Continent. Royalist sympathisers nevertheless contrived to avail themselves of the Prayer Book privately in their households and, in the relatively tolerant Commonwealth period, were occasionally able to attend semi-public Prayer Book services conducted by sequestered Church of England clergy. ${ }^{26}$

The Royalists' devotion to the Book of Common Prayer made it virtually inevitable that a version of the Prayer Book and an episcopal form of church government would be reinstated on Charles II's restoration in May 1660. In the Declaration of Breda issued the previous month the king, by nature a pragmatist, had promised to bind up the country's "bleeding wounds" and grant freedom of religion to tender consciences. He now made overtures to some of the most eminent clergy who had served in the Commonwealth church and authorised the setting up a commission to discuss the revision of the Prayer Book. This conference met in March 1661 at the Savoy in London. Richard Baxter put the case for reform, arguing at length for extensive modifications in the liturgy and for a toleration for those clergy who could not accept certain rites and ceremonies. Antagonised by his pedantry, the episcopal party refused to grant any concessions, and the delegates dispersed with nothing achieved. The task then passed to the bishops, and, at the eleventh hour, a group of Laudian clergy attempted to resurrect the much more conservative 1549 Prayer Book. The majority of churchmen, however, regarded this as a

Revue Française de Civilisation Britannique, XXII-1 | 2017 
step too far and the Book of Common Prayer approved by the Convocations of Canterbury and York in December 1661 was in all essentials identical with the Prayer Book of $1552 .{ }^{27}$

At this juncture the bishop of London, Gilbert Sheldon, determined to restore the church to the state in which it had been before the Civil War, turned to the newly elected Cavalier Parliament to outmanoeuvre the king and his chief minister, the earl of Clarendon, who were still hoping for a more inclusive and conciliatory religious settlement. He gained his objective through the patient marshalling of sympathisers in the Lords and Commons, and clauses were inserted in the new Act of Uniformity decreeing the only episcopally ordained clergy, who had repudiated the Solemn League and Covenant and declared in public their "unfeigned assent and consent to all and everything contained and prescribed in 監....區 the Book of Common Prayer", might hold livings in the English church. The Act received the royal assent on 19 May and came into force on St Bartholomew's Day, 24 August, 1662. ${ }^{28}$

31 From the death of Edward VI until the Civil War, Protestants who had difficulty in reconciling the church's liturgy with its theology had nevertheless considered themselves full members of the English church. Even late in Elizabeth's reign, Richard Hooker felt able to maintain that "there is not any man of the church of England but the same is also a member of the commonwealth, nor any member of the commonwealth, which is not also of the church of England". No theologian could make such a claim with any plausibility after the Restoration. The refusal of hard line Episcopalians first to sanction any substantial modifications to the Prayer Book and subsequently to allow leniency to tender consciences in the Act of Uniformity resulted in the ejection of around two thousand ministers with their congregations in the space of two years between the fall of the republic and Black Bartholomew's Day. The re-adoption of the Book of Common Prayer in 1662 thus marked the end of a comprehensive church in England. ${ }^{29}$ It is, therefore, somewhat ironic that it was the more "Romish" aspects of Prayer Book worship - so very controversial in the first century of its use- that most contributed to the position of Anglican worship as a unique resource for various churches on the Continent since the 19th century across historic denominational divides. More than "Romish", of course, these elements of worship were the result of continuity of liturgical practice from the Middle Ages, through the Henrician break with Rome, to the Edwardian Reformation and the Elizabethan Settlement.

\section{NOTES}

1. F. Procter and W. H. Frere, A New History of the Book of Common Prayer (London, 1901), 45-90; B. Cummings, ed., The Book of Common Prayer: the Texts of 1549, 1559 and 1662 (Oxford, 2011).

2. E. Arber, ed., A Brief Discourse of the Troubles at Frankfort 1554-1558 (London, 1908), 77; spelling in all quotations has been modernised. 
3. Cummings, ed., The Book of Common Prayer, 186-92; J. Bruce, ed., Correspondence of Matthew Parker (Parker Society, Cambridge, 1853), 65; H. Robinson, ed., The Zurich Letters (Parker Society, Cambridge, 1842), 23; P. Collinson, The Elizabethan Puritan Movement (London, 1967), 32-6; D. J. Crankshaw and A. Gillespie, 'Parker, Matthew (1504-1575), archbishop of Canterbury and patron of scholarship', Oxford Dictionary of National Biography (Oxford, 2004), vol. 42, 707-28 [hereafter ODNB].

4. Cummings, ed. The Book of Common Prayer, 192; J. Ayre, ed., The Sermons of Edwin Sandys (Parker Society, Cambridge, 1841), 443; Collinson, Elizabethan Puritan Movement, 65-6; B. J. Kidd, The Thirty-Nine Articles: Their History and Explanation (London, 1899), 38-54.

5. Collinson, Elizabethan Puritan Movement, 50-51, 54-55, 69; C. Cross, Urban Magistrates and Ministers: Religion in Hull and Leeds from the Reformation to the Civil War, Borthwick Paper 67 (York, 1985), 14-15; C. Cross, 'Gilby, Anthony (c.1510-1585), religious writer and Church of England clergyman', ODNB, vol. 22, 213-14.

6. Zurich Letters, 162, 175-181; Collinson, Elizabethan Puritan Movement, 68-95.

7. W. H. Frere and C. E. Douglas eds., Puritan Manifestoes (London: SPCK, 1907, reprinted 1954), 8-55.

8. Puritan Manifestoes, 21, 29, 30, 35.

9. Puritan Manifestoes, 23.

10. W. Nicholson, ed., The Remains of Edmund Grindal (Parker Society, Cambridge, 1843), 378, 379, 382, 383, 389-90; P. Collinson, Archbishop Grindal, 1519-1583: the Struggle for a Reformed Church (London, 1979), 233-252.

11. Collinson, Elizabethan Puritan Movement, 245, 264.

12. P. Collinson, J. Craig, B. Usher, eds., Conferences and Combination Lectures in the Elizabethan Church: Dedham and Bury St Edmunds 1582-1590, Church of England Record Society 10 (Woodbridge: Boydell Press, 2003); Collinson, Elizabethan Puritan Movement parts 6,7 and 8 .

13. Ayre, ed., Sermons of Edwin Sandys, 448.

14. F. Shriver, 'Hampton Court Re-visited: James I and the Puritans', Journal of Ecclesiastical History, 33 (1982), 50-1.

15. Shriver, 'Hampton Court Revisited', 54-63.

16. Shriver, 'Hampton Court Revisited', 66.

17. N. Tyacke, Anti-Calvinists: the Rise of English Arminianism, c. 1590-1640 (Oxford, 1987); A. Milton, Catholic and Reformed: the Roman and Protestant Churches in English Protestant Thought, 1600-1640 (Cambridge, 1965); J. P. Kenyon, The Stuart Constitution 1603-1688 (Cambridge, 1966), 158.

18. K. Fincham and N. Tyacke, Altars Restored: the Changing Face of English Religious Worship 1547c.1700 (Oxford: Oxford University Press, 2007).

19. P. Slack, 'Thatcher [Thacher], Peter (1587/8-1641), Church of England clergyman', ODNB, vol. 54, 207-9; P. Slack, 'Religious Protest and Urban Authority: the Case of Henry Sherfield, Iconoclast', Studies in Church History, 9 (1972), 295-302; J. Chandler, Endless Street: A History of Salisbury and its People (East Knoyle, Salisbury, 1983), 201-2.

20. Borthwick Institute of Archives, York CP H 2123 Responses of John Birchill; R. A. Marchant, The Puritans and the Church Courts in the Diocese of York 1560 - 1642 (London, 1960), 74 - 106.

21. Borthwick Institute of Archives HC AB 19 f. 115 r.

22. P. King, 'The Reasons for the Abolition of the Book of Common Prayer in 1645 ', Journal of Ecclesiastical History 21: 327-39; A. Hughes, "'The Public Profession of these Nations": the National 
Church in Interregnum England', in C. Durston and J. Maltby, eds., Religion in Revolutionary England (Manchester, 2006), 94.

23. King, 'Reasons for the Abolition of the Book of Common Prayer', 333-4; J. Maltby, Prayer Book and People in Elizabethan and Early Stuart England (Cambridge, 1998), 92-3.

24. Maltby, Prayer Book and People, 109, 113-14, 127.

25. King, 'Reasons for the Abolition of the Book of Common Prayer', 336-7.

26. J. Maltby, 'Suffering and Surviving: the Civil Wars, the Commonwealth and the Formation of “Anglicanism”, 1642 - 60', in C. Durstan and J. Maltby, eds., Religion in Revolutionary England (Manchester, 2006), 158-201.

27. J. Spurr, The Restoration Church of England, 1646-1689 (New Haven and London, 1991), 30-41.; Cummings, ed., The Book of Common Prayer, 757-8, 769.

28. J. Spurr. 'Sheldon, Gilbert (1598-1677), archbishop of Canterbury', ODNB, vol. 50, 178-85; Spurr, The Restoration Church of England, pp.41-2; Cummings, ed., The Book of Common Prayer, 196, 198.

29. R. Hooker, Of the Laws of Ecclesiastical Polity (London, 1666), Book VIII, 448.

\section{ABSTRACTS}

The parliamentary settlement of religion of 1559, which in the Acts of Supremacy and Uniformity recognised the monarch as the supreme governor of the English church and required the church to worship according to the only slightly modified, indisputably Protestant second Prayer Book of Edward VI, had long lasting political consequences, since it automatically made any questioning of the Prayer Book a potential infringement of royal authority. The Prayer Book had undergone radical changes in the short reign of Edward VI and committed Protestants, who repeatedly questioned whether the liturgy prescribed in the Prayer Book accurately reflected the theology of the national church, assumed that the crown would authorise further revision. The disappointment of their expectations in the century between the accession of Elizabeth and the restoration of Charles II contributed in no small way to the destruction of a comprehensive Protestant church in England in 1662.

Après l'avenement d'Elizabeth Ière, le Parlement rétablit la suprématie royale et la loi d'uniformité imposa à toute l'Eglise une version légèrement revisée du second Book of Common Prayer d'Edouard VI, liturgie clairement protestante. Ces decisions en matière de religion eurent un impact politique durable : toute remise en cause du livre de prières pouvait être comprise comme une atteinte à l'autorité royale. Entre sa première et sa seconde edition, toutes deux sous le règne d'Edouard VI (1547-1553), le Book of Common Prayer avait été profondément transformé. Les protestants les plus engagés, qui exprimait régulièrement leur malaise face à ce qu'ils voyaient comme un décalage entre la liturgie officielle et la théologie de l'Eglise nationale, étaient convaincus que la reine engagerait de nouvelles réformes. Du règne d'Elizabeth jusqu'au retour de Charles II sur le trône, leurs attentes furent décues et cette déconvenue explique en grande partie les profondes divisions de l'Eglise d'Angleterre qui empècherent la restauration d'une Eglise unifiée en 1662. 
INDEX

Mots-clés: Book of Common Prayer, Elisabeth Ière, puritains, dynastie Stuarts, Eglise d'Angleterre

Keywords: Book of Common Prayer, Elizabeth I, puritans, Stuart kings, Church of England

\section{AUTHOR}

\section{CLAIRE CROSS}

University of York 